\begin{abstract}
"Mircea cel Batran" Naval Academy Scientific Bulletin, Volume XX - 2017 - Issue 1
The journal is indexed in: PROQUEST / DOAJ / Crossref / EBSCOhost / INDEX COPERNICUS I DRJI / OAJI I

JOURNAL INDEX / I2OR / SCIENCE LIBRARY INDEX / Google Scholar / Academic Keys/ ROAD Open Access I Academic Resources / Scientific Indexing Services / SCIPIO / JIFACTOR
\end{abstract}

\title{
TRANSPORTS IN ROMANIA
}

\author{
Florin DOBRE ${ }^{1}$ \\ ${ }^{1}$ Lecturer Ph. D. OVIDIUS UNIVERSITY CONSTANTA, THE LAW SCHOOL AND ADMINISTRATIVE \\ SCIENCES
}

\begin{abstract}
Transport system is not only the connection between economic branches and the circulation system on trade in goods between the different states of the world, but also an important factor in the training population GDP and employment. Without a system to transport organized at the global level can be achieved international economic trade and cannot integrate in the world of all areas and geographical regions of the world and cannot benefit from the advantages of globalization.

Efficiency of economy depend not only on technical quality or productivity, but also to transport quality in all modes of transport.
\end{abstract}

Keywords : transport on the water,priority projects

\begin{abstract}
Introduction
" Transport Services represents a branch of the national economy means include all road, shipping and airline which provides movement of persons and the circulation of material property. Shipments have a contribution consequence in the development of economy, their share in the GDP ranging between 3-7 \%, in most world's countries. Transports development has eliminated economic insulation permitted development of trade and national economies and international".
\end{abstract}

\section{THE ANALISIS OF THE EVOLUTION OF TRANSPORT IN ROMANIA}

Transport Network in Romania is ......./Downloads/HTTP quite varied, this country should be from this point of view to an acceptable level compared to other countries. Urban transport operations are inside cities but and long-distance toll charges. The emergence and development of transport in Romania is closely linked to both of the other structures of the police and of the development of the means of communication in our country, which they have taken momentum in the second half of 19th century, like a large part of Europe, feeling need for commercial links between safe and rapid West Europeans and the eastern Europe and further to east.In Principalities United States first railway, what he was doing connection between Bucharest and Giurgiu, was inaugurated in the year set up in 1869 but in the Transylvania under the Austro-Hungarian occupation there is already a network of railways relatively developed for that time. With the passage of time and with socio-economic development of the country, the network of railways shall be increased continuously, and also the traffic of goods and passengers Danube, in particular after the first world war, and with increasing the number of passengers and the volume of goods carried appears and the need for the protection of them. So in the year 1929 appears Regulation for the transport service at border posts, in ports and stations and in the year 1936, at the request of Autonomous Direction of Railways, there shall be set up first legion of gendarmes CFR who brought out additional income earned by this and a change of order and discipline imposed on travelers. In the following year appears the Law 118 of exploitation of Romanian Railways, have a special chapter relating to the detection of infringements by transport communication in stations and in ports.

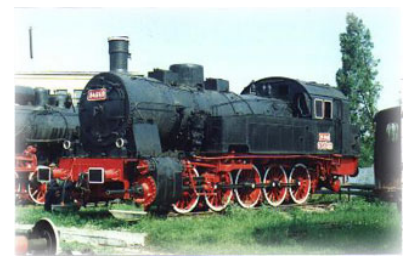

Road transport.The greatest competitive advantage of road transport is its ability to carry goods throughout Europe and on the whole continent, with a unmatched flexibility at a low price.

Transport by rail between 1980 and 2012 the market share of rail transport has fallen down from 21,15 to $8.4 \%$.

Air transport. Of all types of transport, air transport has had the largest increase in the past 30 years.

Sea and inland waterway transport

Transport on the water is the least used and developed even if it is not a cheap way of transport and is less pollutant than road.

At the present moment in Romania there is no official statistics on number of persons who use motor vehicles personal property, but only those relating to long-distance and international traffic. So in the year 2012 there have been a total of 384.515 .000 passengers, they 296.954 .000 , (77 $\%)$ have traveled by road, and 78.252 .000 , (20\%) 


\section{"Mircea cel Batran" Naval Academy Scientific Bulletin, Volume XX - 2017 - Issue 1 \\ The journal is indexed in: PROQUEST / DOAJ / Crossref / EBSCOhost / INDEX COPERNICUS / DRJI / OAJI I JOURNAL INDEX I I2OR / SCIENCE LIBRARY INDEX / Google Scholar / Academic Keys/ ROAD Open Access I Academic Resources / Scientific Indexing Services / SCIPIO / JIFACTOR}

have chosen the train as a means of transport. Plane has been preferred by about 9.077.000 people, the remaining passengers preferring the inland waterways and sea.

\section{TRANSPORT GROWTH IN EU COUNTRIES}

Transport represents an area of socio-economic activity that achieves moving material property and of the people in the space, by means of vehicles or special installations, on certain traffic routes, in order to meet the material and spiritual necessities of the company.

Development of transport has been imposed on the development always ascending of the factors of production. Many advancements in science and technology, more or less spectacular at that time, have been placed in the service base development and modernization technical materials for transport which, in its turn, was able to ensure that people with a broad range of services in a time of less. Continual increase the volume of production materials, the need to exchange of goods, the need for travel from long distances of goods and people have constituted factors promoters of ascending development of transport, of vision advancing labor and within the framework of this activity.

A decisive influence on the development of the transport had, for example, inventing machine with steam, which has facilitated the emergence of railways, navigation using oceanic sea-going vessels and set in motion by the force steam. A number of other developments in technology: construction first automobile powered by an internal combustion engine (1855); the invention of the internal ignition combustion engines (1899); inventing the first plane ( $N^{\circ} 1905 / 83$ (9), ) "there are many events that will mark progress and diversification transport (transport auto appearance and then the air).

At present, transport has become an indispensable element of life, whereas society offers members of possibilities of travel, communication, for the collection and assimilation, as much of what gives civilization. Modern civilizations, characterized by an intense pace of development in the various areas, through a massive exchange of material and spiritual values, complain of a continuous movement of goods, a permanent movement of people from one place to another.

Economic Development of any country increases considerably the volume of economic goods created and emphasizes the mobility of population within urban settlements. In the transport sector will not be created economic goods, but also services, and for this reason, production in this field of activity is expressed in units of measure abstract.

The effect on the economy transport
Transport is one of the most important branches of the national economy. In Romania transport, together with the storage and communications, represents almost $10 \%$ of the GDP.

Transport growth, the emergence of new means of transport improved and specialized allowed specialization and exchange of activities, training and national market of the world market, development of trade on the domestic and international.In addition to the impact on the economy of the country shipments have and implications for social aspects ( tourism, health, education, culture) and political.

The transport activities, especially those railways and aircraft, are capital-intensive requiring massive investments, accessible only corporate.

At the same time transport offers great opportunities for economies of scale, so that there is a large proportion of fixed costs which are distributed on a larger number of users to reduce unit costs.As with all services, the transport service cannot be stored. Therefore, it is necessary to develop and the organization of the base solid technical materials, technical and commercial speed of the means of transport, the full utilization of their capacity to eliminate transport through the empty or with partial load, so that the transport needs of the company can be met with minimum expenditure of social work. Transport system is not only the connection between economic branches and the circulation system on trade in goods between the different states of the world, but also an important factor in the training population GDP and employment. Without a system to transport organized at the global level can be achieved international economic trade and cannot integrate in the world of all areas and geographical regions of the world and cannot benefit from the advantages of globalization. Efficiency of economy depend not only on technical quality or productivity, but also to transport quality in all modes of transport.

No member cannot develop economic and neither the people may not have access to a degree of civilization as far as acceptable without a transport system developed and well organized.

\section{Transport in Romania}

Transport Network in Romania is quite varied, this country should be from this point of view to an acceptable level compared to other countries. Urban transport operations are inside localities but and long-distance toll charges. Through the share of $9.8 \%$ branch of transport and communications in the GDP, Romania is among the most well positioned countries, and there is positive and the fact that labor productivity is higher than in other classes, whereas this sector occupies only 4.9 percent of the total workforce. 


\section{"Mircea cel Batran" Naval Academy Scientific Bulletin, Volume XX - 2017 - Issue 1 The journal is indexed in: PROQUEST I DOAJ / Crossref / EBSCOhost / INDEX COPERNICUS / DRJI / OAJI I JOURNAL INDEX I I2OR / SCIENCE LIBRARY INDEX / Google Scholar / Academic Keys/ ROAD Open Access I Academic Resources / Scientific Indexing Services / SCIPIO / JIFACTOR}

These figures confirm excellent geo-strategic position of Romania and accentuates excellent prospects for our country to become a major link connection between east and west and Central Europe, becoming a real transit station in the Black Sea basin.

All statistics show that, during the period 20122017, transport have had a positive development, the routing of goods (measured in million tonnes$\mathrm{km}$ ) increased by $74 \%$. By far, the most significant growth has occurred at a road transport: $254,9 \%$.

An interesting phenomenon was surprised by statistics is the fact that, in the last quarter of the year 2011 and until the end of May of this year, the transport carried out by means of transport of the Romanian was greater than the value obtained with foreign means, so that the balance of payments and receipts in the field of transport services has become positive (plus 13 million euros in the first five months of 2012, as compared to a balance of minus 17 million euros in the same period of 2015).

If we take into account the declarations of the officials, we should put up with the idea that, for transporters in Romania will handle it and that even in time of crisis infrastructure in all modes of transport will be modernized, by the construction of motorways in a rhythm or by adding a financing railway infrastructure and aircraft.

\section{Structure of the network of public transport}

The public network infrastructure in Romania includes:

(A) public railway network that covers, practical,all over the country.

Density of lines on the holding of $46,1 \mathrm{~km} / 1000$ $\mathrm{Hmp}$, provides the connection to all railway networks of neighboring countries.

Network length is $10,981 \mathrm{~km}$ and was served in a territory of 1051 of stations and staging of the railway, 50 depots and discounts of locomotive, 120 service wagons and workshops on the area and 106 polling stations maintenance on the lines, art works and installations of centralization and telecommunications.

At present, the entire rail network is in the process of rehabilitation and modernization to allow passenger trains to move with a speed of $160 \mathrm{~km} / \mathrm{h}$ ). In the long term, will be carried out maximum speed of $200 \mathrm{~km} / \mathrm{h}$ for passenger trains and $120 \mathrm{~km} / \mathrm{h}$ ) for freight.

(B) road network published,which provides access motorized in most localities. Network density is $0.64 \mathrm{~km} / \mathrm{kmp}$; the length is the network of $73,435 \mathrm{~km}$ (only street) of which $14,685 \mathrm{~km} 1$ ) (20\%) national roads $(4,672 \mathrm{~km}$ European roads of which $113 \mathrm{~km}$ motorways) and 58.7502 ) km roads county and local budgets.
From the point of view of the degree of modernization public road network holds $24.6 \%$ $(18,084 \mathrm{~km})$ roads upgraded, $28.4 \%(20,836 \mathrm{~km})$ roads with lightweight coverings road and $47 \%$ $(34,515 \mathrm{~km})$ roads gritted and the earth. National Roads network constitute majority of the country, on them as indicated approximately. $70 \%$ of the road traffic.

To make the traffic in general, and to prevent heavy traffic in towns, the Ministry of Public Works, Transports and Housing provided for a program to construct variants of the by-pass of cities in Craiova, Timisoara, Pitesti and Sibiu. Following the completion of projects of rehabilitation and of the work of progress of major repairs to national roads have improved technical parameters of these roads, reducing the length roads with the operational life expired and resulting in an increase in the capacity of the road and the safety of crossing over the railway lines by the construction of uneven passages.

(C) inland waterway network is located entirely in the south and south-east of Romania with a density of $6.5 \mathrm{~km} / 1000 \mathrm{kmp}$.

Network length is $1,779 \mathrm{~km}$ of which $1,075 \mathrm{~km}$ Danube waterway international, $524 \mathrm{~km}$ inland waterway arms of the river Danube and $91 \mathrm{~km}$ inland waterways man-made vitreous (Danube Black channels and the gate Alba-Navodari ). On the network of inland waterways and the Black Sea are integrated 35 ports of which 3 ports, 6 ports river- maritime and 26 ports inland waterways. Romanian ports feature about. $49,000 \mathrm{M}$ triplet for berthing of vessels, of which $18.1 \%$ older than 50 years, requiring urgent rebuilding.

(D) The network airline shall be constituted in the Romanian airspace in which define routes depending on traffic flows coordinated at European level by Eurocontrol.

The Romanian airspace, i.e. airways, are used for both overflight while securing of the supervisory service and route the air traffic as well as for taking-off and landing on airports, they are thus connected with airports around the world. Airport system in Romania is made up of 17 airports, of which 4 are open to traffic domestic and international passenger and cargo and 13 are specific to local interest.

Specific objectives make reference to :

Road modernization of the network of national interest where particular attention will be given construction of motorways, Approx. 1052 KM will be build in this period. Will be upgraded and constructed circuitous variants in length approx. $301 \mathrm{Km})$.

Modernization of equipment and airport facilities in the four airports of national interest, in order to 


\section{"Mircea cel Batran" Naval Academy Scientific Bulletin, Volume XX - 2017 - Issue 1 The journal is indexed in: PROQUEST I DOAJ / Crossref / EBSCOhost / INDEX COPERNICUS / DRJI / OAJI I JOURNAL INDEX I I2OR / SCIENCE LIBRARY INDEX / Google Scholar / Academic Keys/ ROAD Open Access I Academic Resources / Scientific Indexing Services / SCIPIO / JIFACTOR}

allow an increase in traffic of passengers at 11.3 million passengers per year in 2017.

The objective general and specific objectives of national development priority "The Development and modernization of the transport infrastructure" is done by actions grouped into three subpriorities :

1) Modernization and development of infrastructure trans-European transport networks and connection element which will generate territorial cohesion between Romania and the $\mathrm{EU}$, by reducing travel times to the main destinations.
2) Modernization and construction of road infrastructure trans-European;as fa watch complete motorways under construction, construction of new highways and roads construction quick circuitous variants of cities situated on TEN-T and the modernization of roads and bridges from TEN-T.

Priority projects will also imply the construction of the highway branch north of the corridor Pan European IV between localities Nadlac - Arad Timisoara - Lugoj - Deva - Sibiu - Pitesti, Bucharest, Constanta.

Section of motorway for the period 2007-2017

\section{CONCLUSIONS}

The transport activities, especially those railways and aircraft, are capital-intensive requiring massive investments, accessible only corporate.

At the same time transport offers great opportunities for economies of scale, so that there is a large proportion of fixed costs which are distributed on a larger number of users to reduce unit costs.As with all services, the transport service cannot be stored. Therefore, it is necessary to develop and the organization of the base solid technical materials, technical and commercial speed of the means of transport, the full utilization of their capacity to eliminate transport through the empty or with partial load, so that the transport needs of the company can be met with minimum expenditure of social work.

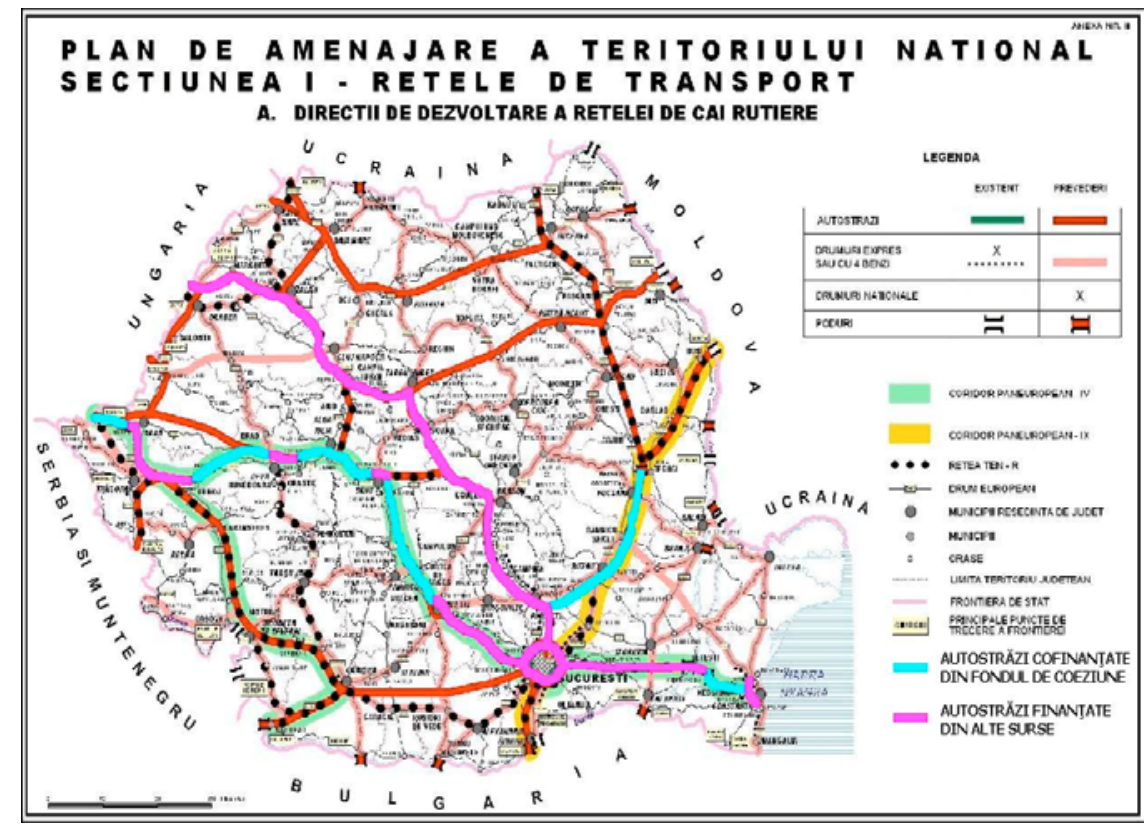

\section{BIBLIOGRAPHY}

[1] "The network of the European transport 2020 GDP - rail International, Belgium 2005 - Camelia Pavel

[2] "SERVICES" ECONOMY 2007- Viorica major battlefield

[3] Information material documentary- technical information No 5/2005

[4] ***WWW.transport.ro

$[5] * \star *$ WWW.IGPR.ro 